\title{
Arte e cultura, matrizes implícitas ao processo comunicativo
}

\section{Simone Maria Rocha e Guilherme Santana}

\section{Resumo}

0 presente artigo pretende apresentar duas matrizes de orientações conceituais distintas - a artística e a cultural - que subsidiam tratamentos diversos acerca do cinema no Campo da Comunicação. Inicialmente, serão evidenciados os desdobramentos que cada matriz suscita no que tange à compreensão do processo comunicacional. Por fim, as matrizes artística e cultural serão avaliadas quanto à capacidade de problematizar a relação entre comunicação e politização.

\section{Palavras-Chave}

Cinema. Arte. Cultura.
Simone Maria Rocha I smarocha@ig.com.br Doutora em Comunicação e Cultura pela Universidade Federal do Rio de Janeiro - UFRJ, Pós-doutorado em Comunicação Social pela Universidade Federal de Minas Gerais - UFMG. Professora do PPGCOM/ UFMG e coordenadora do Grupo de Pesquisa em Comunicação, Mídia e Cultura (COMCULT).

Guilherme Santana I gugasant@bol.com.br Mestre em Comunicação Social pela Universidade Federal de Minas Gerais - UFMG.

\section{Introdução}

Em artigo anterior (ROCHA E SANTANA, 2014), tendo como pano de fundo uma divergência interpretativa entre Robert Stam (1981) e Paul Ricoeur (2010) acerca do conceito aristotélico de mímesis, procurou-se enfatizar a heterogeneidade conceitual presente no interior do campo da comunicação. Foi realizada uma análise semântica dos termos arte e cultura com 0 objetivo de demonstrar que o tipo de apropriação destes conceitos é tributário das delimitações estabelecidas pelas linhas de pesquisa do campo comunicacional. Ao final do percurso empreendido, observou-se com maior clareza a existência de duas matrizes de orientação conceitual que competem pela hegemonia dos estudos sobre cinema, a saber, as matrizes artística e cultural.

Uma perspectiva centrada no estudo do produto, ao separar a obra de seu contexto social de produção, tende a compreender a arte a partir de uma dimensão imanente, preocupando-se com a decupagem de uma dada obra, visando a avaliar se 
sua constituição interna se adequa a parâmetros de validação julgados como apropriados. No caso específico das proposições apresentadas por Robert Stam, os parâmetros de validação incluem a adoção de um regime representacional específico - 0 anti-ilusionista -, bem como 0 estabelecimento da finalidade artística da obra como criação, por parte do artista, de um novo mundo possível. Em consonância com esta perspectiva, o significado de cultura pode ser interpretado de duas maneiras: 1) 0 ato do indivíduo de subjetivar um acervo de experiências canônicas; 2) uma forma de designar o próprio acervo de experiências canônicas desenvolvido no interior de uma sociedade.

Contrapondo-se a esta abordagem centrada na análise da obra de maneira isolada, uma linha de pesquisa que focalize o estudo da comunicação como uma prática social deve possuir, em seu senso comum, um entendimento diferente dos vocábulos arte e cultura. A própria hierarquia entre os conceitos é invertida, ou seja, a arte é tomada como uma expressão da cultura. Neste sentido, a cultura corresponde à demarcação de um campo comum de significados que constitui a identidade dos indivíduos e os permite agir e viver em sociedade. A partir desta acepção de cultura, a arte diz respeito à construção de um mundo específico, resultado de um processo de cooperação entre indivíduos e da definição de significados que visa a rotular experiências sociais como portadoras de valor artístico (BECKER, 1977). De uma perspectiva situada na avaliação das características intrínsecas ao objeto, a arte passa a ser compreendida como um processo particular de atribuição de significado; a imanência cede lugar à contingência. Este deslocamento, possibilitado pela restituição da arte à vida social, tem a vantagem de explicar os processos de mudança que a noção de arte sofre historicamente, além de reconhecer que 0 significado deste termo não é unívoco, consensual. Neste contexto, o presente artigo tem a intenção de avançar sobre uma problemática aberta pelo seu predecessor. Uma vez que os significados dos conceitos modificam-se no interior de uma linha de pesquisa, por consequência, é plausível supor que o próprio entendimento do processo comunicativo seja divergente no âmbito de cada uma destas instâncias do campo. Este trabalho, portanto, se presta a observar o modo como arte e cultura, tomadas como matrizes de orientação teórico-metodológica subjacentes no interior deste campo de conhecimento, vislumbram formas específicas de se compreender tanto o cinema como o próprio fenômeno da comunicação.

\section{0 modelo comunicacional segundo a matriz artística}

A perspectiva artística, conforme já evidenciado, está fundada no estudo de uma relação específica, qual seja, aquela estabelecida entre 0 artist $a$ e a obra de arte. Não por acaso, 0 tipo de analítica adotada está centrado em uma discussão de ordem estética. Isolada das suas condições sociais de produção, a obra é julgada em sua singularidade 
através do estabelecimento de parâmetros, sobretudo formais, considerados válidos:

Devemos começar a sublinhar que 0 tipo de discurso que aqui estudaremos preocupa-se antes mais com os filmes, considerados enquanto obras em si mesmas, independentes, infinitamente singulares. (...) Só muito acessoriamente abordaremos os discursos sobre 0 filme que 0 encaram de um ponto de vista exterior à obra: existe um discurso jurídico, sociológico, psicológico sobre o filme, e tantas abordagens quantas as ciências humanas. Distingui-las-emos da análise do filme propriamente dita. (AUMONT \& MARIE, 2009, p.11)

No plano da dinâmica comunicativa, o estudo da relação existente entre artista e obra de arte tem como implicação fundamental conferir centralidade ao momento da produção da mensagem. Deste recorte epistemológico, depreendem-se duas crenças visivelmente compartilhadas pelos pesquisadores do meio - ainda que, muitas vezes, não admitidas publicamente -, responsáveis por sustentar uma visão transmissiva acerca do funcionamento das práticas comunicativas. A primeira destas crenças diz respeito à suposição de que 0 verdadeiro

artista possui controle total sobre 0 processo produtivo de sua obra. Em termos estritamente comunicacionais, trata-se da capacidade do indivíduo de dominar integralmente o processo de significação de sua obra. Esta crença está assentada no princípio de que todos os significados presentes no interior de uma obra de arte são intencionais. Não surpreende, portanto, que, na maioria das vezes, o processo de decupação de um filme consista na espírita tentativa de recriar, de maneira inversa, todos os passos e escolhas realizados por um cineasta, a fim de que "sua" obra atingisse a conformação final que veio a público.

Todas as tensões que marcaram o processo produtivo da forma fílmica são diluídas pela magia de um autor que assume responsabilidade integral sobre a versão última do produto - ato este discursivamente negado, embora metodologicamente assumido, cuja consequência fundamental parece ser apenas e tão-somente mitificar a ideia romântica do $\operatorname{artista}^{1 \mid 2}$. A desmontagem de um filme é frequentemente

Como contraponto a essa visão idealizada sobre o fazer cinematográfico, Edward Buscombe (2005) cita a contribuição de Peter Wollen a respeito de uma engraçada contradição: os realizadores são bastante distintos das estruturas que tomaram seus nomes. Neste sentido, o próprio processo de interpretação da filmografia de um realizador implica em um procedimento de concordância do discordante, uma vez que diz respeito à tentativa de conferir um significado a um conjunto de episódios (no caso, obras) distintos - e, por vezes, contraditórios. Deste movimento decorre uma flagrante disjunção: recorrências temáticas e artifícios de composição fílmica celebrados pela crítica como acessos da genialidade e marca distintiva quando confrontados com a opinião dos próprios cineastas sobre suas crias se revelam procedimentos involuntários ou secundários. 0s artistas, portanto, não são totalmente conscientes do seu processo produtivo como se desejou pressupor.

Se, por um lado, Robert Stam faz questão de enfatizar a denúncia da ideologia da transparência enquanto forma de manutenção do sistema social por meio de uma expressão "artística" alinhada com os interesses dominantes, por outro, ao negligenciar o caráter histórico-social da arte quando a concebe enquanto um domínio autônomo, extra-social, paradoxalmente incorre no erro da ideologização do indivíduo, mais precisamente no cultivo romântico do mito do gênio artístico provavelmente tributário da influência da política dos autores sobre sua concepção de cinema. Stam parece não levar às últimas consequências a irônica constatação do escritor polonês Witold Gombrowicz (2006), segundo a qual não apenas 0 artista cria a forma como a forma também cria o artista. É de se estranhar que Stam aponte como alienante a identificação do espectador com a obra de arte, mas não encare do mesmo modo a identificação do pesquisador com 0 artista. 
confundida com a produção do mesmo; a

interpretação de uma obra é assumida como 0

autêntico processo de elaboração da mesma ${ }^{3}$.

Decorrente da primeira, a segunda crença enxerga

a obra de arte como instância de significação

autossuficiente. A fim de refinar 0 entendimento da

asserção imediatamente anterior, a querela travada

entre 0 diretor de cinema pernambucano Kleber

Mendonça Filho, "autor" do filme O Som ao Redor, e

o diretor da Globo Filmes Carlos Eduardo Rodrigues

se mostra extremamente elucidativa. A troca de

farpas teve início quando, em entrevista ao jornal

Folha de S.Paulo, Mendonça citou que o simples

aparato econômico da Globo Filmes seria garantia de

sucesso de público: "Minha tese é a seguinte: se meu

vizinho lançar 0 vídeo do churrasco dele no esquema

da Globo Filmes, ele fará 200 mil espectadores

no primeiro final de semana"4. Em resposta à

provocação, Rodrigues ofereceu gratuitamente

o suporte da Globo Filmes para que Mendonça

dirigisse um longa-metragem sob a condição de que

caso a obra em questão não atingisse o público de

200 mil espectadores, 0 cineasta se comprometeria

a dizer publicamente que "como diretor, ele é, talvez,

um bom crítico". Dando prosseguimento à cordial

"conversa" pela internet, o diretor escreveu uma

interessante réplica ao executivo:
Olá Cadu

Estava em trânsito o dia inteiro, cheguei em Istambul onde 0 Som ao Redor será exibido nos próximos dias. 0 Facebook e a imprensa ferviIham com nosso embate. Preciso lhe agradecer pelo desafio, mas sua proposta associa a não obtenção de uma meta comercial (200 mil espectadores) como prova irrefutável de que eu não seria um cineasta.

Isso não me parece correto, pois o valor de um filme, ou de um artista, não deveria residir única e exclusivamente nos número\$. Sobre ser crítico ou cineasta, atuei como ambos e meu discurso permanece o mesmo, e sempre foi colocado publicamente, e não apenas em mesas de bar: 0 sistema Globo Filmes faz mal à idéia de cultura no Brasil, atrofia o conceito de diversidade no cinema brasileiro e adestra um público cada vez mais dopado para reagir a um cinema institucional e morto.

Devolvo eu um outro desafio: Que a Globo Filmes, com todo o seu alcance e poder de comunicação, com a competência dos que a fazem, invista em pelo menos três projetos por ano que tenham a pretensão de ir além, projetos que não sumam do radar da cultura depois de três ou quatro meses cumprindo a meta de atrair alguns milhões de espectadores que não sabem nem exatamente 0 porquê de terem ido ver aquilo. Esse desafio visa a descoberta de novos nomes que estão disponíveis, nomes jovens e não tão jovens que fariam belos filmes brasileiros que pudessem ser bem visto\$, se o interesse de descoberta existisse de membro tão forte da cadeia midiática nesse país, e cujos produtos comerciais também trabalham com incentivos públicos que realizadores autorais utilizam.

A título de exemplo, chama a atenção o modo como Robert Stam (1981) praticamente assume a voz de Godard para justificar como objetiva sua leitura pessoal da obra deste cineasta; soa como se Stam soubesse exatamente o que Godard quis exprimir em cada plano de cada um de seus filmes: "enquanto um filme sonoro convencional apresenta um analogon duplo de som e imagem, que se reforça mutuamente, Godard faz com que os dois destruam um ao outro" (STAM, 1981, p.173); "Godard seguiu o conselho desses cineastas, utiliza o som para des-realizar a imagem tornando-a, assim, abstrata” (STAM, 1981, p.172).

Disponível em: http://www.diariodepernambuco.com.br/app/noticia/viver/2013/02/20/internas_viver,424490/diretor-da-globofilmes-faz-desafio-ao-diretor-pernambucano-kleber-mendonca-filho.shtml Acesso em: 10 mar. 2014. 
Não precisa me incluir nessas novas descobertas, gosto do meu estilo de fazer cinema. Ainda estou no meio de um grande desafio com 0 Som ao Redor, 9 cópias $35 \mathrm{~mm}$, mais algumas salas em digital, chegando aos 80 mil espectadores em 8 semanas, e com distribuição comercial em sete outros países. A maior publicidade de 0 Som ao Redor é o próprio filme. Para finalizar, esses embates são importantes, fazemos cinemas diferentes, em geografias diferentes.

Obrigado, tudo de bom. Kleber

A argumentação de Mendonça ilustra com muita propriedade o modelo comunicacional que subjaz às teorizações desenvolvidas no interior da matriz artística. A supramencionada questão da autossuficiência da obra de arte se refere, neste contexto, ao caráter totalizante que a obra adquire quando compreendida à luz de um entendimento estreito do processo comunicativo. Trocando em miúdos, a abordagem artística parte da pressuposição de que a obra seria responsável por determinar integralmente 0 modo como os sentidos que partilha são recebidos pelos indivíduos. Desprovidos de autonomia, os receptores não passam de um efeito construído a priori pela própria obra de arte quando de sua produção pelo artista. No âmbito do cinema, isso significa dizer que na configuração de um filme já está presumido o modo como seus espectadores assimilarão a narrativa exibida.

Segundo este panorama, a comunicação é entendida como um procedimento de transmissão de valores baseado na especulada simetria entre os significados codificados pela instância produtiva e aqueles decodificados pelos receptores - qualquer eventual divergência sobre os valores, por consequência, é assumida como um problema de comunicação; a figura do artista incompreendido é exemplar a este respeito. Em sua fala, Mendonça explicita esta compreensão de comunicação quando diz que as obras exibidas pela Globo Filmes "adestram 0 público", público este que, para o cineasta, "sequer sabe o real motivo de ocupar as salas de cinema".

0 belo discurso de Mendonça recupera a questão da legitimidade da comunicação: se 0 filme é baseado em ditames estritamente artísticos, sua comunicação é legítima; entretanto, se o filme é subsidiado por uma indústria cinematográfica, trata-se de uma comunicação ilegítima, nociva. Os receptores em nenhum momento são tratados como indivíduos portadores de senso crítico senão enquanto massa de modelar, cuja qualidade da comunicação a que são submetidos seria correspondente à qualidade da forma que viriam a assumir. A alienação, segundo este viés, recebe status de estado de natureza do indivíduo.

Este entendimento transmissivo da dinâmica comunicativa justifica 0 apego à dicotomia brechtiana entre os regimes representacionais

Para o dramaturgo alemão Bertolt Brech, a utilização do modo de representação ilusionista expressaria cumplicidade com a ideologia capitalista à medida que a mediação da técnica seria apagada através do emprego de convenções realistas de narração. 0 teatro brechtiano, base das considerações sobre cinema escritas por Robert Stam (1981), propõe a ruptura com a dinâmica de identificação entre 0 espectador e a obra de arte. Esta é a premissa da noção de anti-ilusionismo, ou seja, promover a quebra da ilusão de que a arte é um prolongamento da vida. Esta ruptura com a identificação possibilitaria a construção de um pensamento reflexivo por parte dos espectadores. Para realizar a experiência do choque, Brecht pregava a desconstrução das convenções naturalistas de narração. 
ilusionistas e anti-ilusionistas ${ }^{5}$, afinal, dada a fragilidade dos receptores, que sequer conhecem 0 caminho de suas próprias casas, o verdadeiro cinema deve ocupar um papel pedagógico anti-ideológico. A experiência do choque, que marca a proposta do cinema anti-ilusionista, pretende despertar os espectadores de seu estado de natureza através da quebra da identificação com a narrativa filmica e, assim, conduzi-los ao caminho do bem, quer dizer, à "reflexão", à descoberta do indivíduo crítico escondido no interior de cada ser humano. Cabe à arte e, em particular, ao Cinema a tarefa de ensinar o indivíduo a pensar. Em suma, a comunicação é reduzida a um maniqueísmo cuja solução implícita seria a ocupação dos meios de comunicação pelas bondosas camadas artístico-intelectuais, a priori progressistas e cultivadas - cabe aqui a capciosa pergunta: será que os cultivados já foram algum dia alienados? A sensibilidade artística, mais do que propriamente força motriz de um pensamento efetivamente "crítico", serve prioritariamente como medida de distinção social entre os indivíduos, pois à mesma se costuma vincular uma autoridade de fala que se coloca como natural e não gosta de ser contestada. Frequentemente celebrada como forma de resistência ao totalitarismo, pouco se costuma dizer sobre o totalitarismo proveniente da arte, cuja aura de sacralidade que a envolve serve como um dogmático álibi.

A fim de não aceitar o desafio de Rodrigues, Mendonça evoca a mencionada sacralidade artística. Seu modo de proceder torna patente a dicotomia arte pura $x$ capitalismo que está na raiz de seu pensamento. Ingressar na Globo Filmes, em vez de uma oportunidade de ampliar seu diálogo com os espectadores, significaria contaminar o livre curso de sua "expressão pessoal". A princípio, tal recusa parece servir apenas à reafirmação mítico-social do lugar do artista como marginal, rebelde, "autônomo". Entretanto, a postura de Mendonça, quando analisada com mais acuidade, contradiz o modelo de comunicação que evoca. Afinal, o diretor poderia fazer uso da própria engrenagem do sistema econômico para incutir nas "acéfalas massas" uma crítica contundente a este mesmo sistema opressor e, através disso, realizar o processo pedagógico que, em tese, deveria balizar a verdadeira arte.

Se, por um lado, o diretor pernambucano, de fato, acerta quando diz que a qualidade de uma obra não pode ser medida unicamente pelo retorno financeiro, por outro desconsidera que tampouco a mera atribuição do rótulo artístico a um determinado produto atesta verdadeira qualidade ao mesmo - postulado este que parece ser 0 ponto de partida de sua retórica. Neste contexto, soa demasiadamente ingênua a dicotomia entre cinema comercial $x$ cinema não comercial de que, implicitamente, Mendonça se vale para construir sua réplica ao diretor da Globo Filmes, pois tal dualismo é marcado por uma enganosa imanência no que tange à qualidade dos filmes. Para um posicionamento que se pretende original, as palavras de Mendonça parecem mais uma colagem de clichês sobre a relação entre a arte e os meios de comunicação. 
0 testemunho do cineasta pernambucano torna evidente que o modo de pensamento que fornece sustentação à narrativa da tese de Robert Stam (1981) possui, ainda hoje, bastante pregnância social. Em que pese as mais de três décadas de aniversário da publicação do texto de Stam, sua retórica é ainda bastante atual e verossímil para determinadas interpretações sobre 0 cinema. Ademais, cabe ressaltar que a fala de um cineasta não é substancialmente diferente do modo como os analistas de cinema costumam conceber a dinâmica comunicativa no ambiente acadêmico.

\section{0 modelo comunicacional segundo a matriz cultural}

Conforme evidenciado, a matriz de pensamento artística concebe a obra de arte como seu ponto de partida e também de chegada. Deste gesto analítico, como não poderia deixar de ser, esta abordagem infere um modelo de comunicação que confere primazia à obra. Fundada na crença de que 0 artista é a origem da obra de arte, automaticamente a comunicação é reduzida a uma prática espírita, a saber, trata-se do esforço de restaurar o verdadeiro pensamento codificado pelo artista. A perspectiva culturalista, entretanto, não acredita que o recorte de estudo artista - obra de arte seja suficiente para explicar, com maior grau de complexidade, o modo como a comunicação se processa na vida social. A fim de fornecer uma nova perspectiva de entendimento da dinâmica comunicativa, a análise culturalista propõe que se abandone a tirania da obra e se investiguem, primeiramente, as condições necessárias à inteligibilidade da mesma (MARTÍN-BARBER0, 2003). Apenas assim será possível, em um segundo momento, regressar à obra com um olhar mais apurado e compreender qual sua real dimensão no interior do processo comunicativo.

Neste sentido, o corte primário a ser traçado consiste na ruptura com a difundida ilusão de que 0 artista é 0 ponto de origem de uma obra de arte. Esta asserção se revela falsa em dois sentidos. Primeiro, porque o sistema produtivo de uma obra, como mostrou Howard Becker (1977), jamais está concentrado apenas nas mãos de um único indivíduo - o que é ainda mais flagrante em uma atividade de caráter eminentemente industrial como o cinema. Segundo, porque, para uma obra ser comunicada, assumindo que seu desejo seja realmente este, é necessário que, anteriormente, a mesma seja passível de reconhecimento pelo público. Para tanto, presume-se como précondição para o reconhecimento da obra a existência de um terreno comum que seja capaz de vincular tanto os indivíduos responsáveis pela sua produção como também aqueles aos quais a obra em questão convoca para ocupar o lugar de espectadores. Portanto, a origem de uma obra diz respeito, na verdade, ao terreno comum que permite à mesma ser identificada e usufruída. 0 terreno comum, bem que se diga, é demarcado e estabelecido pela cultura, entendida como um sistema de significados que organiza as relações sociais, cuja materialidade se dá pela linguagem através das práticas comunicativas (HALL, 2003). 
Ao corte acima operado corresponde, implicitamente, uma mudança de compreensão sobre 0 significado da noção de indivíduo: de uma perspectiva subjetiva, este passa a ser concebido a partir de uma perspectiva cultural. A matriz artística costuma assumir a individualidade como um traço inato. Por conseguinte, a comunicação é vista como um mero veículo de ligação entre subjetividades isoladas - entendimento este que Mikhail Bakhtin (2006), no âmbito da linguagem, chamou de subjetivismo idealista. A ênfase colocada sobre a necessidade de expressão individual também justifica a preocupação em conceber 0 ato comunicativo como uma espécie de transferência telepática, à medida que vislumbra certa tentativa de alcançar a essência de um indivíduo. Em contrapartida, na matriz de pensamento culturalista, a individualidade é construída através das práticas comunicativas. Longe de ser apenas um meio de ligação entre subjetividades distintas, segundo este viés a comunicação constitui o próprio processo de formação da identidade individual; é a matériaprima da ficção a que se atribui o estabilizador nome eu (HALL, 2006). Há de se ressaltar, todavia, que o reconhecimento do caráter cultural do indivíduo não implica que as apropriações individuais da cultura ocorram de maneira idêntica. Isso se explica tanto pelo fato de a cultura não ser um sistema de significados homogêneo, como também por conta da opacidade inerente à linguagem; a comunicação não é assumida como um processo impositivo, senão interpretativo. A ação dos indivíduos é balizada pela interpretação que os mesmos realizam da realidade social em que estão inseridos. Disso se depreende a impossibilidade de assegurar que todos os indivíduos possuam os mesmos padrões de resposta diante de circunstâncias semelhantes que venham a enfrentar. Não se pode, portanto, inferir que, em uma troca comunicativa, haja uma simetria de interpretações entre os parceiros envolvidos, afinal, os mesmos possuem uma história de vida singular e carregam consigo repertórios culturais específicos que servem como parâmetro para a avaliação de suas respectivas interpretações. Diferentemente do que advoga a perspectiva artística, os receptores não são tábula rasa.

Uma vez arado o terreno conceitual, um novo entendimento comunicativo para 0 cinema se torna viável; a obra pode, então, ser restituída à dinâmica comunicativa. Para tanto, o recorte de estudo artista - obra de arte cede lugar a outro, qual seja, cultura - produto cultural. A opção por produto cultural em detrimento de obra de arte obedece ao reconhecimento de que a experiência cultural não pode ser restrita apenas àqueles objetos que recebem 0 selo de legitimidade artística, afinal, os objetos não artísticos também são portadores de uma dimensão epistemológica importante sobre as práticas culturais vigentes em um dado momento histórico. Neste novo panorama, o filme é compreendido como uma instância de mediação entre a esfera produtiva e o público receptor.

Como primeiro momento analítico do modelo comunicacional, a dimensão da produção 
corresponde ao processo de configuração da narrativa cinematográfica, isto é, do trabalho envolvido em transformar a linguagem cinematográfica em uma forma fílmica específica. Inicialmente, deve-se considerar que o produto final a ser exibido é fruto das tensões que marcam o envolvimento de diversos indivíduos que agem conjuntamente para a elaboração de um filme. Ainda que a paternidade dos filmes contemporaneamente costume ser atribuída à figura do diretor, cabe reafirmar novamente que 0 mesmo é apenas uma das peças da engrenagem necessárias à realização de um longa-metragem. Além disso, é necessário destacar que a configuração narrativa de um filme obedece a um procedimento de codificação de significados culturais. Não se trata, evidentemente, de uma hiper-intencionalidade ideológica, tal como presume a matriz artística, mas, na verdade, da constatação de que os indivíduos envolvidos no processo produtivo estão inseridos na cultura e, diante disso, a narrativa filmica fornece 0 registro de uma compreensão possível acerca de algum aspecto desta mesma cultura. Com frequência, as escolhas elaboradas para conferir materialidade à linguagem cinematográfica vislumbram uma tentativa de fechamento do significado aos eventos que são encenados. Poder-se-ia admitir, deste modo, a existência de uma leitura preferencial reivindicada pelo filme.
Enquanto instância de mediação, entretanto, a forma-mensagem cinematográfica ao ser compartilhada socialmente passa a ser portadora de uma autonomia relativa (SIMMEL, 1998) ${ }^{6}$. Dito de maneira direta, a codificação cultural pretendida pela instância produtiva quando da configuração da narrativa ao fim e ao cabo não passa de uma possibilidade de interpretação, dentre outras existentes e passíveis de serem acionadas para um dado filme; a película se torna independente das intenções de seus produtores. Paul Ricoeur (2010) compreende com perspicácia esta dinâmica quando assinala que no interior de uma determinada obra está virtualmente contida a sua antiobra.

Transitando entre os polos típicos da obra e da antiobra está o público receptor. Em que pese a tentativa de fechamento do sentido proposta pelas escolhas da instância produtora, o circuito comunicativo só é efetivamente concluído, em termos analíticos, através do processo de interpretação do filme. Trata-se, eminentemente, de um momento marcado pelo conflito, afinal, os receptores acionam seus respectivos acervos culturais para confrontar a visão da realidade que acreditam ter sido codificada como pretendida pelo filme. Nesta experiência, ora se aproximam da obra, ao concordar com determinados aspectos da narrativa, ora que pode ser extraída por outras pessoas, mas que não havia sido introduzida por nós mesmos. A realização acabada contém acentos, relações e valores que são de responsabilidade exclusiva de sua existência objetiva, não importando se o criador teve consciência de que isto constituiu o resultado de sua criação". (SIMMEL, 1998, p.99) 
se aproximam da antiobra, ao contestar os rumos seguidos pela trama. Os processos de identificação estabelecidos entre os espectadores e a narrativa encenada, assim, não são unívocos tampouco constantes, como especulava a perspectiva artística por meio de sua aversão declarada ao modo de representação ilusionista.

Segundo este modelo comunicacional, a mediação do produto cultural é compreendida sob a condição de um atravessamento de significados. Neste movimento, nota-se a ampliação dos significados culturais à medida que o processo de transfiguração, tal como denominou Paul Ricoeur, instaura um duplo deslocamento interpretativo. 0 primeiro deles diz respeito ao processo de configuração da cultura sob a forma de uma narrativa cinematográfica. 0 produto cultural, neste sentido, não diz de um falseamento da realidade, mas antes da produção de uma forma de conhecimento a respeito do modo como a mesma pode ser concebida. Não sendo uma dimensão essencializada, só temos acesso à realidade por meio do modo como a interpretamos (BERGER \& LUCKMANN, 2005). Uma vez que a cultura encontra materialidade na linguagem, o filme, enquanto forma de comunicação, efetivamente produz realidade à medida que serve à atualização dos significados da cultura. 0 segundo deslocamento ocorre através do processo de interpretação da narrativa cinematográfica. Em vez de ensinar a pensar, a materialidade do filme fornece elementos para serem pensados pelos indivíduos. Dotada de uma autonomia relativa, a forma fílmica é colocada para avaliação dos indivíduos. Este processo de elaboração dos significados acarreta nova produção de realidade, uma vez que tais sentidos assimilados passam a atualizar o acervo cultural de cada indivíduo e, assim, ajudam a balizar decisões a serem tomadas futuramente. Conforme se pode entrever, neste percurso a cultura assumida como ponto de "origem" do processo comunicativo não possui a mesma estruturação da cultura do momento da "conclusão" da dinâmica comunicativa.

Durante este processo de transfiguração, a noção de ideologia se dissolve no conceito de hegemonia em dois sentidos ${ }^{7}$. Primeiro, quando se afirma a autonomia relativa da forma-mensagem cinematográfica. 0 direcionamento do olhar desejado pela instância produtiva, em termos de valores defendidos, é relativizado pelo sem-número de possibilidades de significação que a narrativa

A acepção mais comum de ideologia corresponde à formulação marxiana, ou seja, à falsa consciência a respeito da realidade social responsável pela produção de alienação. No âmbito da dinâmica comunicacional, esta compreensão apresenta algumas fragilidades, pois o ideológico remete preferencialmente ao econômico - em especial ao capitalismo; é tomado por extra-social, como se fosse imposto verticalmente, arbitrariamente; e é totalizante, isto é, se uma obra recebe esta designação, todos os valores presentes na mesma confluem para a expressão de uma mesma ideologia. 0 conceito gramsciano de hegemonia, embora preencha a mesma problemática da ideologia, parece mais adequado ao estudo do processo comunicativo. Primeiro, porque reconhece a importância da cultura na conformação da vida social. Em segundo lugar, a hegemonia reconhece que nem todos os conflitos sociais derivam apenas de questões materiais. Em terceiro lugar, a hegemonia entende a direção simbólica através de um conflito de natureza heterogênea. 
cinematográfica adquire quando exibida aos espectadores. Segundo, porque as leituras de um filme são tributárias de lugares culturais distintos a partir dos quais os indivíduos dão sentido às suas vidas. A existência de total simetria de interpretações entre a instância produtiva e 0 público receptor jamais é garantida, além de quase nunca ocorrer empiricamente. A justaposiçãa destes dois aspectos supramencionados reforça o fato de que os valores passíveis de serem acionados quando da compreensão de uma obra jamais são homogêneos; na verdade, os mesmos são marcados por ambiguidades, tal como a linguagem. A noção de hegemonia se adequa melhor à opacidade da comunicação por trabalhar as dinâmicas de poder instauradas pelos produtos culturais fora de uma polarização totalizante e totalizadora - como o faz uma noção datada de ideologia -, reconhecendo as contradições e ambivalências características aos processos comunicativos.

\section{Comunicação e politização}

A estação final desta jornada coincide com uma discussão que, de certa maneira, marcou o início dos estudos sobre os meios de comunicação e ainda hoje se constitui como foco de atenção central dos questionamentos levantados no interior do campo da comunicação social e pode ser sumarizada pela seguinte interrogação: qual o potencial político dos meios de comunicação? Embora não exista uma solução definitiva para a indagação, os entendimentos específicos acerca do modelo comunicativo desenvolvidos pelas matrizes de orientação artística e cultural esboçam alguns pontos de partida para avaliar a questão.

\subsection{A politização segundo a matriz artística}

A relação entre a arte e a comunicação mediada tecnologicamente - em especial, o cinema -é historicamente controvertida. Em um primeiro momento, 0 caráter massivo dos meios de comunicação servia como obstáculo à pretensão de singularidade que estaria no cerne da legítima expressão artística. Neste período, o cinema é, taxativamente, negligenciado enquanto forma de expressão artística, pois a arte deveria corresponder à expressão do artista e parecia contraditória a atribuição do rótulo artístico a um tipo de comunicação marcado por um processo produtivo industrial (ADORNO \& HORKHEIMER, 2006). Afinal, a verdadeira arte deveria ser produzida e controlada integralmente pelo artista que, plenamente identificado com sua obra, originaria uma forma singular ${ }^{8}$. 
Por definição, o massivo não era singular - quando muito, pseudossingular. Entretanto, não demorou para que certa apropriação do discurso artístico interpelasse 0 cinema e argumentasse sobre a existência de uma singularidade, de fato, presente na conformação de determinados filmes, uma vez que a difusão massiva, a priori, não impediria a forma autêntica. Na encruzilhada entre optar pelo entendimento adorniano e pelo benjaminiano sobre a relação arte-cinema, concilia-se 0 inconciliável retendo o conveniente de cada uma das concepções: fica a aura de Theodor Adorno! ${ }^{9}$ (negligencia-se a impossibilidade de 0 cinema ser uma autêntica expressão artística nesse sistema de pensamento); fica o potencial político do cinema de Walter Benjamin! (negligencia-se 0 processo produtivo industrial inerente ao cinema). No liquidificador adorno-benjaminiano, há uma luz no fim do túnel: o cinema de arte.

A fronteira estabelecida pelo cinema de arte evoca a legitimidade da comunicação e, automaticamente, serve à separação entre política e entretenimento. 0 pressuposto seria 0 de que apenas uma comunicação de qualidade poderia servir à transformação política. Desse modo, somente 0 cinema de arte seria eminentemente político, uma vez que sua pretensão basilar consistiria em estimular a reflexão dos espectadores. A ideologia, finalmente, poderia alcançar sua crítica; bastaria produzir os filmes da maneira certa. Duas versões do cinema político se destacam. A adorniana enxerga na desconstrução da forma uma via para a politização por intermédio da explicitação de sua faceta não discursiva, isto é, pela experiência estética; não seriam os significados, mas os sentimentos os verdadeiros responsáveis por estimular uma mudança de consciência política. A versão benjaminiana, não desprezando a forma, privilegia a dimensão do conteúdo político da narrativa. Como modelo comunicacional implícito, a reflexão promovida pelo cinema de arte parece se resumir à concordância com os valores apresentados pela narrativa do filme - a reflexão, neste sentido, se refere à reflexão proposta pelo artista impressa sob a forma filmica e não propriamente à elaboração do espectador. 0 peso posto sobre a obra de arte na dinâmica comunicativa compreende os espectadores como mera massa de manobra iletrada.

Acima de qualquer suspeita, a arte se coloca como instância teleológica autêntica à medida que, dada a imanente qualidade de sua experiência, propõe fornecer letramento aos iletrados. A comunicação, neste contexto, é entendida sob a condição de uma forma de pedagogia cuja legitimidade de fala está centrada nas mãos dos artistas e especialistas em arte, responsáveis por conduzir as massas ao pensamento refinado, correto, afinal, estes já sabem como e o que nós precisamos pensar; 
a reflexão, portanto, prescinde da autonomia de pensamento, pois sempre há o perigo de questionar 0 artisticamente estabelecido. Qualquer semelhança com a engenharia social nazista não é mera coincidência - muda-se apenas o motor teleológico: da desacreditada ciência para a arte pura ${ }^{10}$.

\subsection{A politização segundo a matriz cultural}

Partindo de outro entendimento acerca do processo comunicativo, a matriz culturalista oferece uma explicação diferente para o potencial de politização dos meios de comunicação. 0 deslocamento da noção de obra de arte para a de produto cultural reconhece que, independentemente das pretensões comunicativas de um filme, este é dotado de uma dimensão epistemológica. Desta forma, é inconcebível definir, a priori, que filmes de arte sejam feitos para a reflexão, enquanto filmes de gênero sejam produzidos apenas para entretenimento e mais do que isso: é impossível tipificar o engajamento concreto estabelecido entre um espectador empírico e um longa-metragem. Quando as luzes se apagam, as rígidas fronteiras entre reflexão e entretenimento se diluem: tanto um filme de arte também serve ao entretenimento como ninguém esquece 0 cérebro em casa quando vai assistir a um filme de gênero; 0 modo de engajamento entre a obra e a recepção nunca é completamente puro. Ademais, a passagem conceitual da obra de arte para o produto cultural também visa a questionar a superioridade da experiência do cinema de arte, em detrimento do cinema de gênero.

Diferentemente da matriz artística, a abordagem culturalista não crê que a politização possa ser concebida sob a forma de um efeito direto. Isto porque o produto cultural não é a única mediação comunicativa a que os indivíduos têm acesso para construir suas interpretações da vida social. Os processos de socialização dos quais os indivíduos participam são muito importantes na conformação da visão de mundo que os mesmos constroem para orientar suas ações na vida social. Dotado de valores culturais, o espectador negocia os sentidos que alcança no interior de uma narrativa cinematográfica com o quadro de referência que sustenta sua própria cosmovisão. A politização, neste contexto, referese a um processo de elaboração cumulativa e gradual por parte do receptor. Como uma privilegiada arena de debates de interpretações da vida social, os meios de comunicação possibilitam a discussão e a revisão de valores e, assim, explicitam 0 caráter indissociavelmente político das práticas comunicativas, uma vez que estas, ao serem encarnadas no cotidiano, 
atualizam a cultura, fonte de significados que orienta as ações dos indivíduos.

A dimensão política de um filme independe da explicitação do compromisso político. A título de hipótese, é de se supor que quanto mais marcada a comunicação de um filme, mais restrito o seu público consumidor. Em outras palavras, o doutrinamento só satisfaz os doutrinados; em termos de politização, de nada adianta pregar para os convertidos. Neste sentido, um "apolítico" filme como Noivo Neurótico, Noiva Nervosa (1977), dirigido por Woody Allen, parece ter mais sucesso em discutir, a partir do ângulo do humor, as mudanças acarretadas pelo impacto do feminismo na vida social do que o "politizado" Jeanne Dielman, 23, Quai du Commerce, 1080 Bruxelles (1975), dirigido pela feminista Chantal Akerman. Neste filme, Akerman rompe com a convenção narrativa de eliminar os tempos mortos com o objetivo de explicitar 0 caráter opressor do trabalho doméstico na vida das mulheres. Com um enquadramento fixo de câmera, por exemplo, a protagonista é retratada descascando batatas por minutos a fio. Enquanto algumas das feministas respondem ao filme com a sensação de incômodo desejada pela cineasta, entediada, a maioria dos demais espectadores perde 0 teste de resistência e regressa a seus lares antes da película terminar. No limite, a desconstrução completa da forma inviabiliza a comunicação porque a obra corre o risco de não se fazer reconhecível e, assim, não dizer absolutamente nada a ninguém - por mais que os apreciadores de arte assim como 0 artista incompreendido digam o contrário.

\section{Considerações Finais}

A apresentação dos modelos comunicacionais implícitos às matrizes de orientação artística e culturalista serve também para colocar em primeiro plano outra problemática cara aos estudos do campo da comunicação e que poderia ser sintetizada sob a forma de um dualismo da celebração. Em um dos polos da dicotomia, está a cega celebração à arte, que enfatiza a força da obra de arte na conformação dos sentidos e rejeita tudo o quanto não recebe o rótulo de artístico. No outro polo, representado por uma leitura influente, porém simplista da perspectiva culturalista, está a igualmente cega celebração à cultura, que confere demasiado poder aos receptores e defende qualquer produção cultural como modo de resistência. Ao longo deste texto, o que se pretendeu evidenciar com a confrontação entre as abordagens artística e cultural, antes de tudo, foi a fuga a uma concepção apriorística da vida social, que tem caracterizado o ensino no interior deste campo. 0 modelo comunicacional subjacente à matriz de pensamento culturalista, tal como assumido no interior deste artigo, está baseado no estudo da relação estabelecida entre parceiros comunicativos. 0 produto cultural, nesta conjuntura, serve como instância mediadora do diálogo travado. A noção de parceria implica que os interlocutores estejam engajados em uma troca comunicativa, ou seja, que cada um dos momentos do processo comunicativo é portador de uma autonomia relativa. Entretanto, disto não pode se depreender que tais parceiros ocupem 
lugares de fala equivalentes em termos de reconhecimento e poder no interior de uma dada cultura, muito menos que partilhem uma mesma cosmovisão de mundo. Portanto, em que pese um grau de expectativa inerente à construção de um diálogo, este sempre se constitui como uma prática marcada pelo conflito, dada a sua abertura à divergência e ao inesperado. De modo elementar, a tarefa dos analistas da área de comunicação consiste em avaliar os modos e as circunstâncias segundo os quais os processos comunicativos são produzidos e sustentados. Para tanto, não se pode incorrer no erro de partir de fórmulas preconcebidas como "um produto anti-ilusionista é crítico" ou "os receptores são resistentes"; uma forma narrativa "inovadora" não garante que os valores acionados no interior de um filme sejam progressistas ou desenvolvidos de maneira complexa; do mesmo modo, a possibilidade de uma leitura resistente, vislumbrada pelo reconhecimento da reflexividade do espectador no modelo comunicativo dialógico, não assegura que, empiricamente, as leituras de um determinado produto cultural serão, de fato, resistentes. Apenas a análise da situação de comunicação concreta, realizada de maneira isenta e despida de preconceitos, que procure investigar 0 funcionamento das pressões que caracterizam a construção de uma relação entre parceiros comunicativos, poderá endossar ou não a validade de tais assertivas.

\section{Referências}

ADORNO, Theodor; HORKHEIMER, Max. Dialética do esclarecimento. Rio de Janeiro: Jorge Zahar, 2006.

AUMONT, Jaques e MARIE, Michel. A análise do filme. Lisboa: Texto e Grafia, 2009.

\section{BAKHTIN, Mikhail. Marxismo e filosofia da}

linguagem. São Paulo: Hucitec, 2006.

BECKER, Howard Saul. Mundos Artísticos e Tipos Sociais. In: VELHO, Gilberto (org.) Arte e Sociedade: ensaios de sociologia da arte. Rio de Janeiro: Zahar Editores, 1977.

BENJAMIN, Walter. A obra de arte na época de suas técnicas de reprodução. In: 0s pensadores. Textos escolhidos. SP: Abril Cultural, 1975.

BERGER, Peter; LUCKMANN, Thomas. A construção social da realidade: tratado de sociologia do conhecimento. Petrópolis: Vozes, 2005.

BUSCOMBE, Edward. Ideias de Autoria. In: RAMOS, Fernão Pessoa (org.). Teoria Contemporânea do

Cinema Vol. 1, São Paulo: Senac, 2005.

HALL, Stuart. Codificação/Decodificação. In: HALL, Stuart. Da diáspora. Identidades e mediações culturais. BH: Ed. UFMG, 2003.

. A identidade cultural na pós-modernidade. $11^{\mathrm{a}}$ ed. Rio de Janeiro: DP \& A Editora, 2006.

MARTÍN-BARBERO, Jesús. Dos meios às mediações.

Rio de Janeiro: Ed. UFRJ, 2003.

MELLO, Suzana. Considerações sobre a obra de arte: o teatro de Brecht segundo Adorno. Disponível em: http://www.gostodeler.com.br/materia/10390/ consideracoes_sobre_a_obra_de_arte_o_teatro_de_ brecht_segundo_adorno.html. Acesso em: 5 jun. 2014.

RICOEUR, Paul. Tempo e Narrativa. Tomo I. São Paulo: WMF Martins Fontes, 2010.

ROCHA, Simone Maria; SANTANA, Guilherme Antônio 
Carneiro. Arte e Cultura, uma sinonímia imprópria.

Opsis, v. 14, p. 255-278, 2014.

SIMMEL, Georg. 0 conceito e a tragédia da cultura.

In: SOUZA, J; ÖELZE, B. (Org.). Simmel e a

modernidade. Brasília: UnB, 1998.

STAM, Robert. 0 espetáculo interrompido.

Literatura e cinema de desmistificação. Rio de Janeiro, Paz e Terra, 1981. 


\begin{tabular}{|l|l|l|}
\hline \begin{tabular}{|l|l|} 
Art and culture, implied matrices \\
to the communicative process
\end{tabular} & $\begin{array}{l}\text { Arte y cultura, matrices implícitas } \\
\text { en el proceso comunicativo }\end{array}$ \\
\hline $\begin{array}{l}\text { Abstract } \\
\text { This article aims to present two distinct matrices } \\
\text { of conceptual orientations - the artistic and the } \\
\text { cultural - that subsidize various approaches on the } \\
\text { film in the Communication Field. Initially will be } \\
\text { evidenced the developments that each one raises } \\
\text { regarding the understanding of the communication } \\
\text { process. At last, these matrices will be assessed } \\
\text { for the capacity to analyze the relation between } \\
\text { communication and politicization. } \\
\text { Keywords } \\
\text { Cinema. Art. Culture. }\end{array}$ & $\begin{array}{l}\text { Resumen } \\
\text { Este artículo tiene como objetivo presentar dos } \\
\text { conjuntos de directrices conceptuales distintas } \\
\text { - la artística y la cultural - que apoyan diversos } \\
\text { tratamientos sobre el cine en el campo de la } \\
\text { comunicación. Inicialmente se destacarán los avances } \\
\text { cada matriz plantea con respecto a la comprensión } \\
\text { del proceso de la comunicación. Por último, las } \\
\text { matrices artísticas y culturales serán evaluadas } \\
\text { por su capacidad para analizar la relación entre la } \\
\text { comunicación y la politización. }\end{array}$ \\
\hline
\end{tabular}




\section{Expediente}

A revista E-Compós é a publicação científica em formato eletrônico da Associação Nacional dos Programas de Pós-Graduação em Comunicação (Compós). Lançada em 2004, tem como principal finalidade difundir a produção acadêmica de pesquisadores da área de Comunicação, inseridos em instituições do Brasil e do exterior.

\section{E-COMPÓS I www.e-compos.org.br I E-ISSN 1808-2599}

Revista da Associação Nacional dos Programas de Pós-Graduação em Comunicação.

Brasília, v.18, n.1, jan./abri.. 2015.

A identificação das edições, a partir de 2008, passa a ser volume anual com três números.

\section{CONSELHO EDITORIAL}

Alexandre Rocha da Silva, Universidade Federal do Rio Grande do Sul, Brasil Alexandre Farbiarz, Universidade Federal Fluminense, Brasil Ana Carolina Damboriarena Escosteguy, Pontifícia Universidade Católica do Rio Grande do Sul, Brasil

Ana Carolina Rocha Pessôa Temer, Universidade Federal de Goiás, Brasil Ana Regina Barros Rego Leal, Universidade Federal do Piauí, Brasil André Luiz Martins Lemos, Universidade Federal da Bahia, Brasil Andrea França, Pontifícia Universidade Católica do Rio de Janeiro, Brasil Antonio Carlos Hohlfeldt, Pontifícia Universidade Católica do Rio Grande do Sul, Brasil

Arthur Ituassu, Pontifícia Universidade Católica do Rio de Janeiro, Brasil Álvaro Larangeira, Universidade Tuiuti do Paraná, Brasil Ângela Freire Prysthon, Universidade Federal de Pernambuco, Brasil César Geraldo Guimarães, Universidade Federal de Minas Gerais, Brasil Cláudio Novaes Pinto Coelho, Faculdade Cásper Líbero, Brasil Daisi Irmgard Vogel, Universidade Federal de Santa Catarina, Brasil Daniela Zanetti, Universidade Federal do Espírito Santo, Brasil Denize Correa Araujo, Universidade Tuiuti do Paraná, Brasil Eduardo Antonio de Jesus, Pontifícia Universidade Católica de Minas Gerais, Brasil

Eduardo Vicente, Universidade de São Paulo, Brasil

Elizabeth Moraes Gonçalves, Universidade Metodista de São Paulo, Brasil Erick Felinto de Oliveira, Universidade do Estado do Rio de Janeiro, Brasil Francisco Elinaldo Teixeira, Universidade Estadual de Campinas, Brasil Francisco Paulo Jamil Almeida Marques, Universidade Federal do Ceará, Brasil Gabriela Reinaldo, Universidade Federal do Ceará, Brasil Gisela Grangeiro da Silva Castro, Escola Superior de Propaganda e Marketing, Brasil

Goiamérico Felício Carneiro Santos, Universidade Federal de Goiás, Brasil Gustavo Daudt Fischer, Unisinos, Brasil

Herom Vargas, Universidade Municipal de São Caetano do Sul, Brasil
Itania Maria Mota Gomes, Universidade Federal da Bahia, Brasil Janice Caiafa, Universidade Federal do Rio de Janeiro, Brasil Jiani Adriana Bonin, Universidade do Vale do Rio dos Sinos, Brasil José Afonso da Silva Junior, Universidade Federal de Pernambuco, Brasil José Luiz Aidar Prado, Pontifícia Universidade Católica de São Paulo, Brasil Kati Caetano, Universidade Tuiuti do Paraná, Brasil

Lilian Cristina Monteiro França, Universidade Federal de Sergipe, Brasil Liziane Soares Guazina, Universidade de Brasília, Brasil Luíza Mônica Assis da Silva, Universidade de Caxias do Sul, Brasil Luciana Miranda Costa, Universidade Federal do Pará, Brasil Malena Segura Contrera, Universidade Paulista, Brasil Marcel Vieira Barreto Silva, Universidade Federal da Paraíba, Brasil Maria Ogécia Drigo, Universidade de Sorocaba, Brasil Maria Ataide Malcher, Universidade Federal do Pará, Brasil Maria Clotilde Perez Rodrigues, Universidade de São Paulo, Brasil Maria das Graças Pinto Coelho, Universidade Federal do Rio Grande do Norte, Brasil

Mauricio Ribeiro da Silva, Universidade Paulista, Brasil

Mauro de Souza Ventura, Universidade Estadual Paulista, Brasil Márcio Souza Gonçalves, Universidade do Estado do Rio de Janeiro, Brasil Micael Maiolino Herschmann, Universidade Federal do Rio de Janeiro, Brasil Mirna Feitoza Pereira, Universidade Federal do Amazonas, Brasil Nísia Martins Rosario, Universidade Federal do Rio Grande do Sul, Brasil Potiguara Mendes Silveira Jr, Universidade Federal de Juiz de Fora, Brasil Regiane Ribeiro, Universidade Federal do Paraná, Brasil Rogério Ferraraz, Universidade Anhembi Morumbi, Brasil Rose Melo Rocha, Escola Superior de Propaganda e Marketing, Brasil Rozinaldo Antonio Miani, Universidade Estadual de Londrina, Brasil Sérgio Luiz Gadini, Universidade Estadual de Ponta Grossa, Brasil Simone Maria Andrade Pereira de Sá, Universidade Federal Fluminense, Brasil Veneza Mayora Ronsini, Universidade Federal de Santa Maria, Brasil Walmir Albuquerque Barbosa, Universidade Federal do Amazonas, Brasil

\section{COMISSÃO EDITORIAL}

\section{Cristiane Freitas Gutfreind}

Pontifícia Universidade Católica do Rio Grande do Sul, Brasil

Irene Machado

Universidade de São Paulo, Brasil

Jorge Cardoso Filho

Universidade Federal do Reconcavo da Bahia, Brasil

Universidade Federal da Bahia, Brasil

$$
\begin{aligned}
& \text { REVISÃo DE TEXTOS I Press Revisão } \\
& \text { SECRETÁRIA EXECUTIVA I Helena Stigger } \\
& \text { EDITORAÇÃO ELETRÔNICA I Roka Estúdio }
\end{aligned}
$$

COMPÓS I www.compos.org.br

Associação Nacional dos Programas de Pós-Graduação em Comunicação

Presidente

\section{Eduardo Morettin}

Universidade de São Paulo, Brasil

eduardomorettin@usp.br

\section{Vice-presidente}

Inês Vitorino

Universidade Federal do Ceará, Brasil

ines@ufc.br

Secretária-Geral

Gislene da Silva

Universidade Federal de Santa Catarina, Brasil gislenedasilva@gmail.com 